\title{
“E A MINHA VIDA FOI DENTRO DO CARRO, TAXIANDO". TRAJETÓRIAS E OFÍCIO DE “VELHOS” TAXISTAS NO MUNDO URBANO DE BELÉM (PA)
}

Pedro Paulo de Miranda Araújo Soares

Flávio Leonel Abreu da Silveira ${ }^{1}$

\section{O Ofício de taxista em Belém como objeto de pesquisa antropológica}

O presente artigo é fruto de uma pesquisa realizada no contexto urbano de Belém entre os anos de 2007-2008, que consistiu no acompanhamento do cotidiano através da observação e convívio - e em uma a série de entrevistas junto a antigos taxistas ainda na ativa ou aposentados. Esses motoristas foram provocados pelos pesquisadores a refletir sobre o mundo urbano em que atuam como profissionais, cuja dinâmica de labuta consiste em um constante ir e vir marcado pelo deslocamento e deriva no espaço citadino durante décadas.

Tais senhores, através do exercício de rememoração - e a partir da elasticidade de sua memória -, foram capazes de narrar algumas mudanças sofridas na paisagem belemense. Durante tais relatos, as modificações, os dilemas, as possibilidades e os limites do ofício de taxista vieram à tona como elementos indissociáveis do processo de expansão urbana e mudança no/do espaço, vivenciados pelos habitantes da cidade de Belém.

O olhar atento sobre as práticas relacionadas ao ofício de taxista na cidade de Belém ao longo do tempo é capaz de remontar a uma série de questões atuais relativas às transformações ocorridas na metrópole amazônica, ou ainda, indicam as modificações que tomaram assento no mundo urbano belemense desde o século passado. Portanto, tais processos transformativos remontam às formas de viver e praticar os diversos lugares que compõem as paisagens citadinas que sofreram alterações mediante os jogos complexos entre a desterritorialização e a reterritorialização ${ }^{2}$ vividos por seus habitantes. Partimos do pressuposto segundo o qual

\footnotetext{
${ }^{1}$ Ambos os autores do artigo atuam no Laboratório de Antropologia Arthur Napoleão Figueiredo, da Universidade Federal do Pará

${ }^{2}$ Usamos as expressões a partir dos estudos de Perlongher (1989) e de Oliven (1992; 1996) para o mundo urbano.
} 
esses jogos podem ser evidenciados a partir da memória dos taxistas que atuam na capital paraense.

Ao longo da pesquisa de campo foram visitados, principalmente, dois Pontos de Táxi localizados na Avenida Presidente Vargas, região central de Belém. O primeiro deles consiste no ponto da Associação dos Taxistas da Praça da República, situado em frente ao Hilton Hotel, o primeiro cinco estrelas da cidade. O segundo ponto, mais próximo à área comercial da mesma avenida, encontra-se na esquina com a rua Manoel Barata, ao lado do extinto Cinema Palácio e do também extinto Central Hotel, cujo prédio hoje reformado comporta uma grande loja de roupas. No entanto, as conversas com os motoristas desses locais nos levaram a conhecer novos espaços e personagens, como seu Alain - presidente do Sindicato de Taxistas do Estado do Pará -, seu Nascimento e seu Laranjeiras, dois taxistas aposentados, os quais nos receberam em suas respectivas residências.

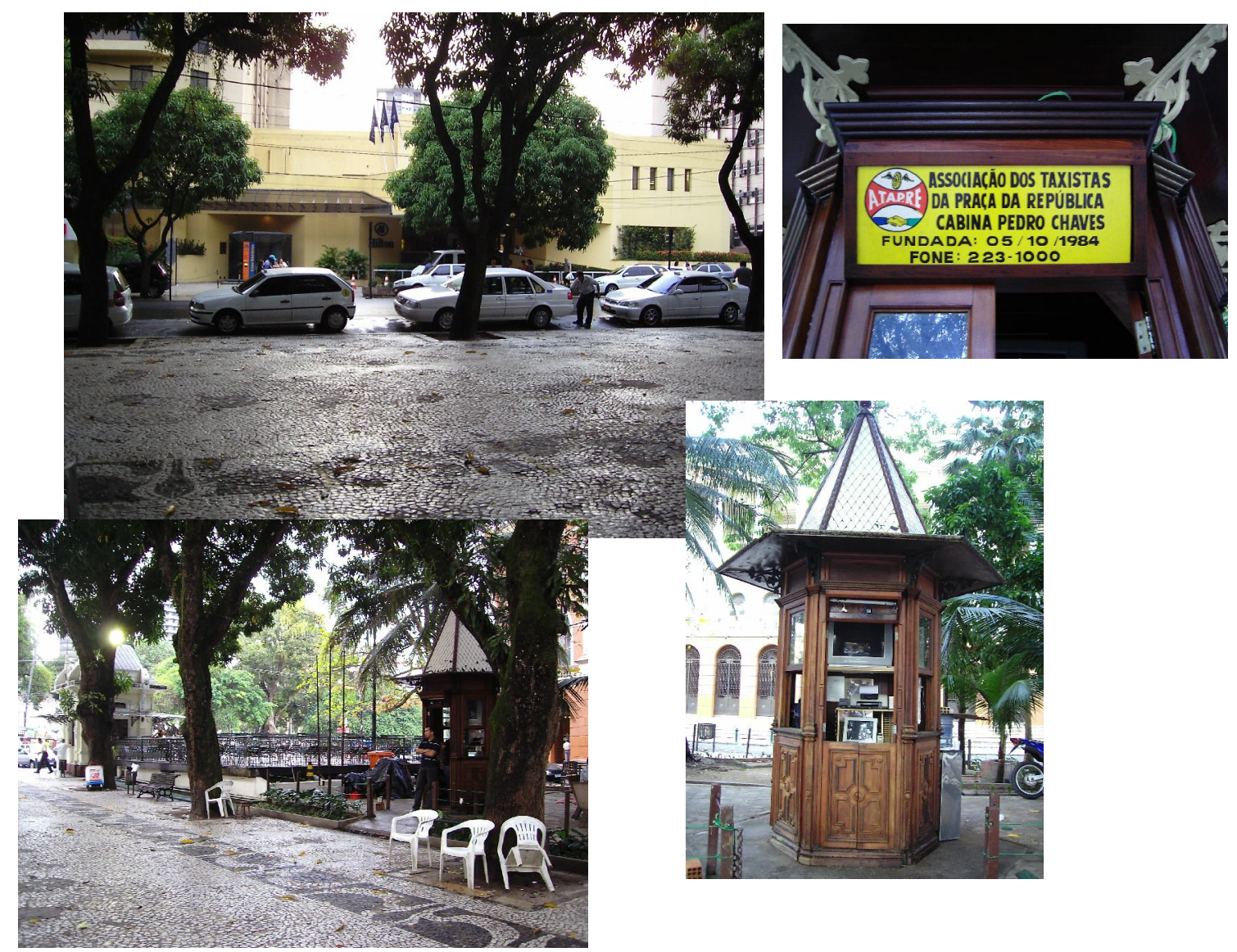


Buscamos, assim, compreender as práticas, os saberes e as narrativas relacionadas ao ofício de taxista, na medida em que estes elementos aparecem como parte de uma memória coletiva (Halbwachs, 2006), que diz respeito ao viver no mundo urbano belemense e, mais especificamente ao deslocar-se com certa constância nele como fazem tais profissionais, uma vez que mapeiam os seus territórios e experienciam as suas mazelas, perscrutando os seus detalhes através do visor do automóvel ao mesmo tempo em que trocam vivências, a partir do diálogo, com os passageiros que guiam pela cidade.

As tensões e conquistas vividas por estes profissionais no presente também constituem uma parcela da experiência urbana de Belém, pois elaboram representações e interpretações sobre a cidade atual, que se fazem sempre em referência às suas histórias de vida como moradores e motoristas na cidade. Os seus olhares, nestes termos, são singulares porque estão relacionados à idéia de movimento. Portanto, avaliam a dinâmica do mundo urbano contemporâneo à luz de suas memórias passadas e a partir de sua condição de condutores de automóveis, revelando uma cidade em constante transformação de seus espaços no decorrer do tempo vivido pelos habitantes da metrópole amazônica.

Neste sentido, a cidade, muito mais que o acúmulo (des)ordenado de concreto e aço, emerge como o locus por excelência da vida social. Dada a sua complexa dinâmica, ela abarca em seu corpo um conjunto de manifestações de labuta, de sociabilidades pontuais e efêmeras próprias às experiências juvenis (Maffesoli, 1987) e de certos enlaces sociais marcados pelos traços da tradição, como encontros de homens em bares para conversar e jogar, passeios nas praças e feiras e, ainda, conversas nas calçadas, por exemplo. Neste mesmo espaço observamos simultaneamente o avanço cruento da violência que desencadeia tensões que revertem nas mais diversas formas de integração e desintegração do social. Tais nuanças do mundo urbano são passíveis de ser evidenciadas a partir do olhar dos personagens citadinos, ou ainda, através de suas narrativas que evidenciam perspectivas possíveis sobre o mundo urbano ${ }^{3}$. Entre eles, os taxistas se destacam pela sua vivência citadina marcada pela intensa mobilidade no espaço urbano.

\footnotetext{
${ }^{3}$ Ver sobre o tema os artigos de Eckert (2000), Eckert e Rocha (2005a) e de Velho (2000)
} 
O taxista é um dos personagens que, por excelência, personifica a idéia de mobilidade e, mesmo, de certa errância no meio urbano, pois possibilita e acompanha a deriva de seus passageiros pela metrópole, visto que dirige o automóvel. Portanto, ao conduzir o carro segundo os desígnios de seus clientes, permite ao outro que adentra a máquina guiada por ele o oscilar entre a labuta e o lúdico, entre a casa e a rua, por exemplo, para usarmos imagens caras a DaMatta (1997).

Sendo assim, os agentes sociais que deambulam no mundo urbano, ao circularem entre as diferentes ambiências onde diversas práticas culturais ocorrem, estão inseridos na dinâmica das paisagens urbanas. Há uma série de sentimentos relacionados, por um lado, ao desprendimento e, por outro, às contingências vividas nessa deriva - apontando para uma experiência cultural que toma a urbe como cenário das ações cotidianas, revelando, por isso, preceitos ético-morais e estéticos, bem como certos vínculos simbólico-afetivos com os lugares de pertença.

Dito isto, é preciso deixar claro que a escolha por motoristas de táxi como "objeto" de nossa pesquisa, revelou ser preciso observar dois pontos teóricometodológicos significativos para o andamento do trabalho de campo: o primeiro diz respeito ao fato de que os interlocutores da pesquisa, dada a sua inserção na vida citadina belemense, constituem parcela importante dos vários grupos urbanos que interagem no âmbito das sociedades complexas (Peirano, 1983; Velho, 2003) no contexto amazônico. O segundo reconhece a possibilidade de pensarmos o "objeto" da pesquisa, como sendo alguém "móvel" (Clifford, 2000) e, ainda, considerando a perspectiva de Perlongher (1989), que poderia ser visto como detentor de uma "territorialidade itinerante" - se considerarmos a cidade como o seu território de deriva e deslocamento constante.

Tal questão colocou-nos a necessidade de acompanharmos as suas movimentações no espaço, de acordo com as vicissitudes dos sujeitos em constante dispersão pelo mundo urbano, em contraponto às abordagens tradicionais que consideravam como locus privilegiado da pesquisa antropológica os locais de moradia/trabalho dos "nativos", isto é, as aldeias. 


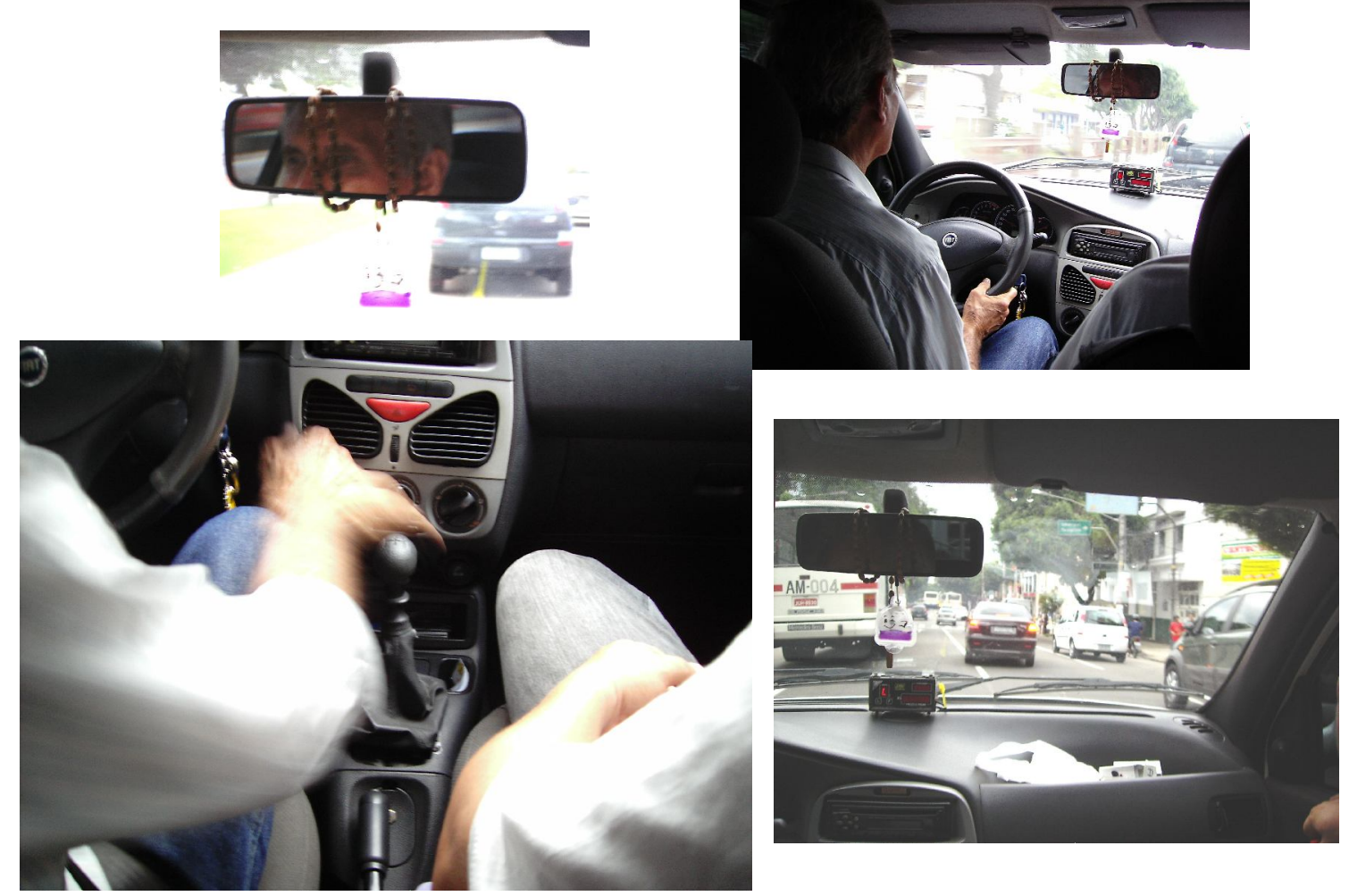

Apoiando-nos no imperativo antropológico de conceder voz ao "nativo" e procurar compreender seu ponto de vista, consideramos neste trabalho a figura do taxista como aquela que remete a um olhar privilegiado sobre a cidade de Belém. Ele faria parte de um grupo específico que testemunhou - e vem testemunhando - as transformações sofridas pela cidade de Belém ao longo do último século: os trabalhadores liberais itinerantes, a exemplo de comerciantes, vendedores ambulantes, carroceiros e motoristas. Dentre esses últimos há o motorista de ônibus, o antigo condutor de trem e o taxista. Os dois primeiros, por não serem autônomos - geralmente estão vinculados a uma firma ou companhia de transportes - e pela própria natureza de seu trabalho, encontram-se circunscritos a uma determinada área da cidade ou a um trajeto específico. Eles não possuem a liberdade de movimentação do autônomo, característica a qual nos interessa para a construção de nosso objeto de pesquisa.

A mobilidade do trabalhador é importante, do nosso ponto de vista, porque o faz um indivíduo livre para escolher seus itinerários dentro do espaço urbano, tomando suas decisões através de suas próprias impressões e interpretações das modificações sofridas pela cidade e sem a intervenção de seus empregadores. Dessa forma, o taxista percorre 
as ruas pavimentadas de Belém e testemunha, através da cabine de seu carro, as mudanças ocasionadas pelo incremento populacional e pelos anseios de modernização presentes nas aspirações de determinadas camadas sociais belemenses ao longo do tempo.

Seu campo de atuação é amplo, pois o taxista normalmente não se recusa a fazer uma corrida a um lugar que considere distante, realizando um processo de desterritorialização necessária advinda da demanda de seu cliente. Isso significa que, por vezes, os taxistas se distanciam por demais de seu ponto e das localidades dentro do espaço citadino as quais estão habituados. Além disso, tal deriva demonstra a fluidez a que se lança em sua labuta, pois a criação e a pavimentação de novas ruas e avenidas tende a acarretar o aparecimento de novos núcleos populacionais, para os quais devem ser conduzidos seus moradores e os visitantes da cidade.

Nota-se que a abertura de novas vias facilita o contato com espaços e realidades outras, o que possibilita ao nosso interlocutor o estranhamente frente a realidades distintas da sua e a "experiência da viagem" (Clifford, 2000) dentro de um mundo urbano complexo como é o belemense. Portanto, o taxista, por vezes, exercita, num certo sentido, algo caro ao antropólogo, ou seja, "o estranhamento do familiar" (Velho, 2004).

O taxista, pela sua circulação intensiva nas ruas da cidade associada aos diálogos travados dentro do carro com personalidades ilustres ou pessoas comuns e, é claro, pela sua vivência como morador de Belém, revela-se, para o caso deste estudo, um exímio conhecedor dos espaços citadinos, porque possuidor de "mapas mentais" (Gell, 1985) do mundo urbano que cobrem tempos passados e atuais. Consideramo-lo, dessa forma, um "guardião da memória" (Benjamin, 1996), pois sua importância reside em uma visão peculiar da cidade, a qual é duplamente privilegiada: em primeiro lugar, pelo tempo de trabalho - alguns dos quais com cerca de 60 anos de labuta -, o qual a memória abarca e organiza; em segundo lugar, pelos espaços percorridos intensamente durante esse tempo.

O locus da pesquisa pode ser representado genericamente pelo Ponto de Táxidefinindo certa fixidez ao caráter "móvel" da profissão - em função de sua predominância ao longo da pesquisa, ainda que tenham sido realizadas visitas à casa de dois motoristas aposentados e ao Sindicato de Taxistas do Estado do Pará.

A imagem do "hotel" evocada por Clifford (2000) ressoa naquela do local de trabalho dos taxistas - o ponto - posto que se trata de um lugar de trânsito e passagem 
de pessoas, desdobrada na circularidade dos motoristas, fenômeno próprio do exercício de sua labuta. A efemeridade das interações e o constante deslocamento que estariam presentes nesta espécie de não-lugar ${ }^{4}$ (Augé, 1994) acabam surgindo, neste caso, como assinaturas ou marcas na oralidade desses motoristas aos quais muitas vezes não é permitido o prazer de uma longa ou detalhada conversa.

Em contrapartida, seu local de trabalho encontra-se na confluência de diversos mundos e cidades, revelando a potência das imagens relativas a uma espécie de expressão nomádica que faz da urbe o espaço de confluência de trajetórias, bem como de derivas e devires dos grupos humanos. Ali, pode ser encontrada uma pequena amostra da diversidade sócio-cultural de uma cidade na Amazônia, na medida em que é possível constatar entre os próprios taxistas uma grande multiplicidade de trajetórias e projetos de vida que seguem a dinâmica dos campos de possibilidades (Velho, 1994), isto é, o leque de opções aberto a esses homens ao longo de suas experiências pessoais que os conduz a e por Belém.

Portanto, o que encontramos na pesquisa nada mais é do que um conjunto complexo de fragmentos de realidade, os quais não se apresentam desconexos, ainda que revelem a "heterogeneidade cultural" belemense. O ponto de táxi, desta forma, situa-se no mundo urbano como o local de trabalho de um grupo específico. Assim, ele assinala um dos lugares freqüentados por estes homens, estando relacionado a apenas um dos tantos papéis representados pelos indivíduos no contexto das sociedades complexas (Velho, 2003).

Levando em consideração o exposto até agora, acreditamos que o velho taxista apresenta-se como um narrador privilegiado, trazendo em seu discurso aspectos da memória coletiva (Halbwachs, 2006) de sua profissão, bem como da memória de antigos moradores da cidade. Observamos que os relatos sobre a seu ofício de motorista podem, em alguns casos, se desdobrar em outras histórias, as quais remetem a um contexto pretérito no qual inúmeras pessoas também vivenciaram as transformações sofridas pelo advento de processos modernizadores no Norte do país.

\footnotetext{
${ }^{4}$ Partindo das reflexões de Marc Augé (1994), temos o "não-lugar" por um local de anonimato, solidão e trânsito de sujeitos que estão à deriva enquanto não alcançam seu destino. O "não-lugar" seria representado pelos hotéis, estações de embarque, interiores de meios de transporte como o próprio táxi, segundo Eduardo Rocha (2004), onde as relações sociais são mediadas pelo aparato tecnológico e não existem vínculos de identidade ou historicidade com os sujeitos que os praticam. É necessário, no entanto, salientar que o "não-lugar" é considerado a partir de perspectivas específicas que são as do viajante e/ou do consumidor.
} 
Na medida em que são rememorados episódios marcantes na vida destes motoristas, a memória exerce a sua "função fantástica" (Rocha e Eckert, 2005b), vinculando novamente imagens guardadas pelos narradores a uma outra experiência de urbanidade. Portanto, este artigo valoriza a experiência da narração acerca do ofício de taxista e suas modificações ao longo do tempo. Estes elementos aparecem como importantes indicadores do viver o lugar e do interagir com os atores sociais no mundo urbano, sendo as narrativas sobre esses temas elementos essenciais de compreensão dos processos de mudança pelos quais vem passando a cidade de Belém.

\section{2. $\mathrm{O}$ antigo motorista profissional: o chofer $^{5}$ de praça}

A pesquisa desde o início buscou centrar-se em motoristas há muito tempo na praça ou aposentados. Paradoxalmente, um de nossos interlocutores mais importantes para a realização do trabalho de pesquisa foi Otávio, de apenas 42 anos. Ele é, no entanto, um dos filhos de seu Pedro Chaves, o fundador da primeira associação de taxistas da cidade de Belém, tendo falecido em 1995. Dessa forma, a memória de Otávio tem como ponto de partida a reconstrução das lembranças do seu finado pai.

Ao relatar a história do ponto no qual o seu pai trabalhou e ajudou a transformar em associação, Otávio acabou trazendo à tona a figura do antigo motorista profissional, denominado outrora, de chofer.

Ah, o ponto era o seguinte: aqui existia um ponto de táxi, não onde você tá vendo agora, você tá vendo agora um ponto de táxi na frente do Hilton Hotel. Mas, em 1980, 1981 não existia hotel. Era o Grande Hotel e tava fechado. Na realidade já era um prédio, já, já tava fechado, já havia anos que o hotel que o Grande Hotel tava fechado (...) Porque naquela época denominava-se o nome de chofer. Quer dizer, a palavra chofer era um sinônimo, que é hoje um táxi, tá! Só que era chofer! Chofer, então, essas pessoas com o tempo se reuniam ali na frente do Bar do Parque, embaixo daquele benjaminzeiro antigo, que é testemunha (...) Então, ali tinha uma gurita. Uma gurita é uma cabine. Não igual a essa, mas uma cabine. Essa cabine, ela tinha um telefone, tinha telefonista, então se chegou a uma organização de ter um número exato, uma série de carros importados e chegou a se ver, eehh, os choferes, chofer, né! Eles todos arrumados, com camisa branca e gravata para atender a

\footnotetext{
${ }^{5}$ Termo derivativo do vocábulo francês chauffer.
} 
classe. Naquela época era a classe média, classe média alta, eles não tinham carro, mas tinham dinheiro!(...) A base disso aqui era casamento, aniversário de 15 anos. Então eles eram muito requisitados pelo telefone pela classe média. Naquela época a palavra chofer era uma palavra de respeito, era uma palavra de, sabe, status! (...) Começou aí. Daí veio a, a, a, colocação (...) o tempo foi se chegando, houve a necessidade, devido à cidade estar aumentando o número populacional, e já existia o nome táxi em outras cidades e veio e chegou aqui. Não me lembro qual foi o governador que liberou as placas de táxi, as primeiras placas de táxi, não me lembro (...) e, daí, na realidade, devido a esse ponto, voltando aos dias de 80,81 , ficou o ponto já como táxi, né. Foi substituído o chofer por táxi.

O que se percebe a partir da fala dos taxistas que viveram o fausto da "época do chofer" é a presença de certa nostalgia, ou ainda, de um fascínio pela figura do chofer, tanto pela sua estética, evidenciada na forma de vestir-se (terno e gravata) quanto pelo prestígio social que possuía na sociedade belemense, visto que poucas pessoas na época estavam capacitadas a conduzir um automóvel. Além da indumentária, outro elemento do trabalho dos antigos motoristas que é objeto de uma espécie de culto por parte de certos taxistas atuais, como Seu Luís (48 anos), são os automóveis da época. Seu Luís através das lembranças relacionadas a um colega já falecido, mencionou os carros que eram conduzidos pelo chofer. Segundo o senhor: "Reginaldo que conta, então, tinha um ponto ali na Praça Brasil que era só aqueles carro bonito, 'Aeroilis', era 'Forrorquéi', só aqueles carro bonito!"

Outro taxista, como seu Laranjeiras (83 anos), que começou a trabalhar na década de 40 do século passado, descreve as condições de trabalho àquela época:

Eu comecei a trabalhar na praça em 1948 , no dia 15 de janeiro de 1948, foi o primeiro dia que eu trabalhei na praça. E em 48 , eu trabalhei (...) no ano de 48, 49, sempre me dando muito bem nos trabalhos de taxista, né. Naquele tempo boas pessoas que trabalhavam comigo, né, como passageiros, como Edyr Proença, Celso Malcher ${ }^{6}$ e muitos outros que se a gente for enumerar assim vai passar muito tempo.

\footnotetext{
${ }^{6}$ Edyr de Paiva Proença foi letrista, advogado, bancário, jornalista e cronista, tendo sido também o pioneiro da radiofonia da Amazônia. Dirigiu, nos anos 90, o Museu da Imagem e Som do Pará. Celso Malcher, por sua vez, foi um dos deputados estaduais que compuseram a Assembléia Legislativa do Estado do Pará durante a década de 1950. Captado em 15/12/2008 no site: www.oparanasondasdoradio.ufpa.br/con50assembleia.htm.
} 
A boa rentabilidade do trabalho do chofer de praça e a convivência com personalidades ilustres revelam, em parte, a confiança e o prestígio social dos quais era depositário o motorista profissional. Ele, portanto, era um profissional especializado, o que contrasta com o ocorrido nos dias de hoje. Segundo muitos taxistas com os quais conversamos, a partir de uma determinada época até os dias de hoje, o mercado passou a sofrer profundas modificações, absorvendo para a profissão de taxista, justamente pessoas as quais não possuíam qualificações profissionais, como outrora. É o que afirma seu Nascimento (72 anos), um taxista já aposentado, ao situar o problema dentro de sua própria experiência de vida:

Eu cheguei à taxista porque na época, na minha época, todo; todas as pessoas tinha suas profissões e o motorista de táxi, ele não estudou. Como eu não estudei. Então naquela altura, de eu não ter estudado, inda cheguei até o terceiro ano primário, e aí eu tive que arrumar o quê? Uma profissão!

Seu Fabiano (aproximadamente 60 anos), um antigo taxista ainda na ativa, partilha da mesma opinião que seu Nascimento, mas atualiza a questão da falta de qualificação profissional do taxista na atualidade:

Belém cresceu um bocado, entendeu! A infra-estrutura que tinha de 70 pra hoje evoluiu muito! O problema é que o mercado de trabalho, hoje, aqui no Brasil é carente. Então a única coisa que o cara sabe fazer se ele aprende a dirigir é tirar a carteira, né, de motorista. E o que é que ele faz? Ele corre logo pra praça!

A questão posta pelos dois senhores, também aparece para seu Fabiano como parte das condições estruturais da vida em sociedade, decorrendo do "crescimento urbano" que prima pela implantação de infra-estrutura - isto é, a pavimentação das ruas e o oferecimento de serviços dos mais variados tipos -, mas que não trata de incluir uma grande parte da população no mercado de trabalho. Ou seja, trata-se da elaboração de táticas de sobrevivência na urbe que são realizadas pelas pessoas que chegam à Belém (Certeau, 1994), por meio de uma série de estratégias postas em prática, visando à inserção no mundo do trabalho frente às limitações do campo de possibilidades que se lhes apresenta no contexto urbano.

O chofer, esta figura singular que permeia a memória coletiva desses profissionais insere-se em um quadro de nostalgia, mas também de interpretação e 
reconstrução de uma determinada concepção de passado. Se tomarmos a questão a partir do que Zukin (2000) coloca, podemos perceber pela fala dos motoristas, o desejo de retorno ao passado provocado pelas lembranças de uma época áurea, o qual poderia indicar "uma reação à 'falta de autenticidade' (...) também uma busca por uma escassa paisagem material da beleza" (Zukin, 2000: 110). Assim, a imagem idônea do chofer aparece nos "jogos da memória" (Rocha e Eckert, 1999) como um personagem antitético em relação às atuais condições de trabalho vividas pelos taxistas, pois indicava naquele período da vida belemense a busca do novo - tão caro à Modernidade - e do autêntico em oposição ao "taxista ladrão" cuja figura Otávio evoca, por exemplo.

O chofer figurava, assim, no cenário glamouroso do Grande Hotel, primando por sua originalidade e pompa. Atualmente, como veremos mais adiante, o mercado de trabalho para os motoristas autônomos encontra-se hipertrofiado ao mesmo tempo em que estes profissionais vivenciam uma série de obstáculos no exercício de seu trabalho.

Percebe-se, mais especificamente na fala de Otávio - pois este fala do Ponto de Táxi onde trabalha -, que há tentativa de estabelecer uma narrativa histórica que justifique a posse daquele espaço, configurando assim, uma espécie de "território" dos taxistas na geografia urbana de Belém. Desse modo, a imagem do chofer ao durar no tempo, ajuda a legitimar a presença do local pelo grupo de taxistas, uma vez que ela evoca imagens, sentimentos e valores relacionados a idéias de "tradição" e de "ancestralidade".

Embora Otávio tenha ratificado a importância do reconhecimento jurídico e formal da Associação de Taxistas da Praça da República, vista como o primeiro ponto organizado de Belém, torna-se relevante, também, observar o papel das narrativas que buscam inscrever uma história no local, revelando os vínculos das pessoas com o lugar, pois tais narrativas atuam como mitos de fundação (Eliade, 2000), auxiliando, no caso dos taxistas, na apropriação simbólica do espaço.

Nota-se, a partir dos relatos de taxistas mais antigos com os quais dialogamos ao longo da pesquisa, que a figura do chofer e, mesmo, do motorista de "carro de praça", ou "carro de aluguel", deve ter existido na cidade de Belém até o final da década de 60. Segundo seu Alain - atual presidente do sindicato dos taxistas - a palavra universal táxi teria chegado à Belém dentro de um contexto especial, pois teria sido "a partir de 70, o Brasil, parece-me que foi injetado de alguma coisa, tanto é que (...) nesses 37 anos, hoje, nós dobramos a população, tá certo, e não acompanhamos esse desenvolvimento, tá certo!" 
Ao referir-se a essa "alguma coisa" que teria sido injetada no Brasil durante esse período, seu Alain coloca as suas impressões sobre as consequiências de tal processo para a cidade de Belém, que não deixa claro, mas que aponta para a inserção da Amazônia naquilo que se chamaria no período ditatorial, de Milagre Brasileiro. A chegada de uma palavra de uso universal como taxi é um pequeno indício de mudanças de modos de vida e de novos anseios modernizadores por parte de segmentos da população belemense, transformando assim, a sua vida urbana.

\section{As Associações e Cooperativas}

Uma das mudanças mais significativas ocorridas nos últimos 20 anos na cidade de Belém é referente à organização de motoristas autônomos em associações e/ou cooperativas $^{7}$. Segundo Otávio tal mudança indica que o ofício de taxista estaria sempre condicionado às demandas sociais e às necessidades que as próprias metamorfoses do espaço urbano impõem. Dessa forma, ele explica o surgimento das associações da seguinte maneira:

Existia o anúncio que o Grande Hotel ia ser demolido pra dar vez a um hotel cinco estrelas. Percebendo isso, o papai, ele observou a necessidade de uma organização, nisso que seria o primeiro hotel cinco estrelas em Belém e, automaticamente, a exigência não seria igual à exigência dos outros hotéis. Teria mais, seria exigido mais coisas, mais organização.

\footnotetext{
${ }^{7} \mathrm{~A}$ diferença entre associações e cooperativas de taxistas residiria, ao menos formalmente, na quantidade de pessoas que cada uma pode comportar. Segundo Neto, um dos diretores do sindicato, os membros de uma Associação podem chegar até 20 pessoas. Ultrapassado esse número de membros, ela precisa adquirir o estatuto de cooperativa.
} 


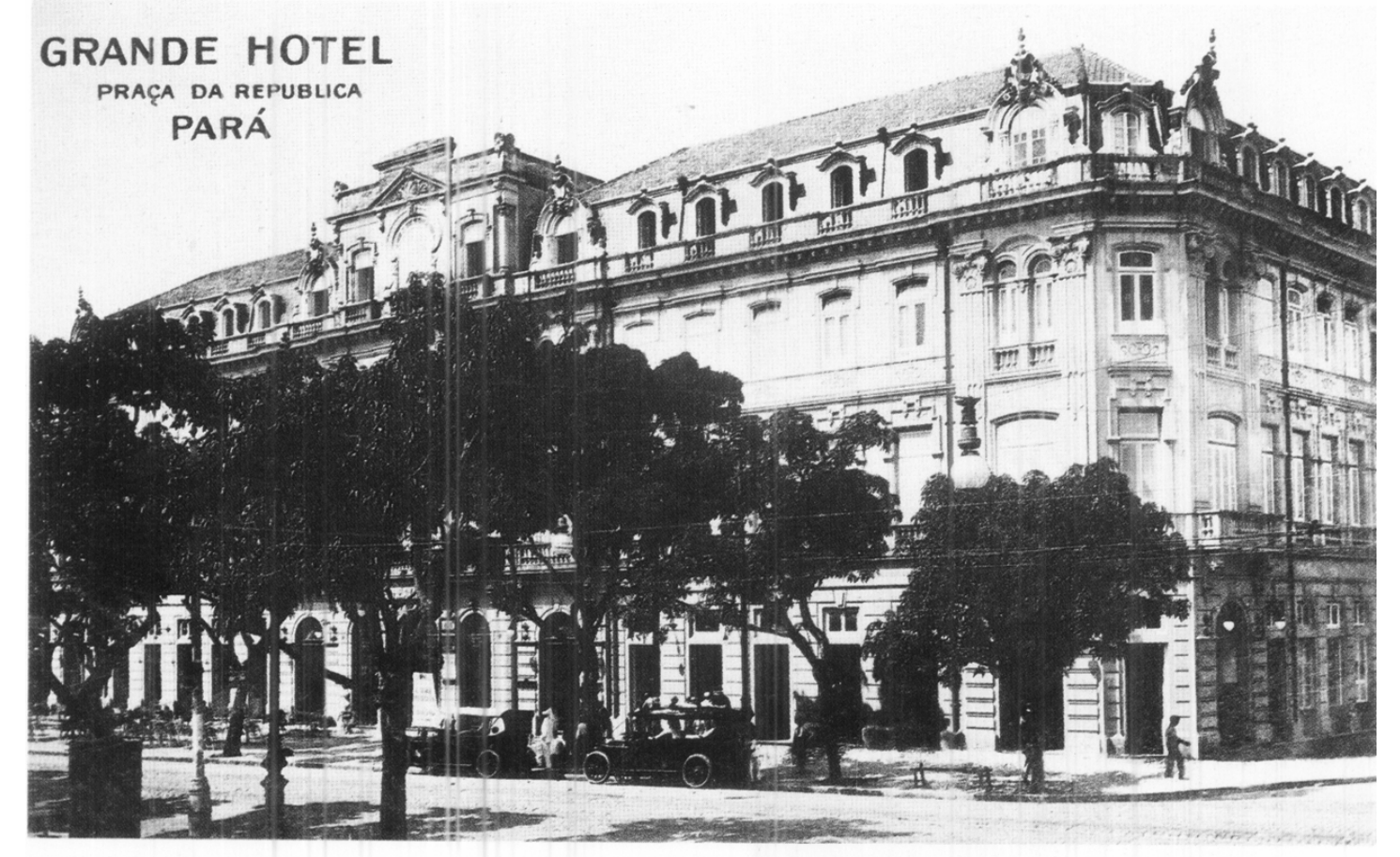

Fonte: BELÉM da Saudade: a memória da Belém do início do século em cartões-postais. Belém: Secult, 1998.

O primeiro fator colocado por Otávio foi a "necessidade de organização" para atender a uma clientela específica, os hóspedes do novo hotel que ainda estava por ser construído. O ímpeto desenvolvimentista revelado na edificação de prédios arrojados, em detrimento das construções de época, trazia à cidade de Belém o estrangeiro (Simmel, 1983) consubstanciado no personagem em movimento que é um verdadeiro signo da modernidade, o turista. No entanto, a "necessidade de organização" está também atrelada a outros fatores externos, os quais por sua vez estariam vinculados a um processo histórico ocorrido em escala nacional. Conforme o motorista:

Na década de 80, explodiu na cidade ondas de violência, começando. Até o final da década de 70, você não via isso! Mas no começo da década de 80 houve uma explosão de violência. Houve também uma, um progresso oriundo de vários fatores, tais quais: a descoberta da Serra Pelada, várias empresas que vieram pra cá, para o Norte quando observaram que havia o minério.

Embora Otávio associe o início de “ondas de violência” aos anos 80, vinculando-os a atrativos que trouxeram levas de migrantes ao garimpo de Serra 
Pelada ${ }^{8}$, enfatizando o caráter local da "crise" que começava a se configurar, no entanto, talvez seja possível considerar que o mesmo acontecia em outras regiões do país.

Os idosos moradores de bairros tradicionais da cidade de Porto Alegre entrevistados por Eckert e Rocha (2005a), também representam os anos 80 como um período em que começa a ser deflagrada uma situação de crise e violência urbana. Podemos, a partir desses depoimentos em diferentes regiões do país, pensar a década de 80 como um período no qual começam a ser sentidas as conseqüências de um projeto de modernização desenvolvimentista e de crescimento econômico, cujas origens se encontram em tempos nos quais o Brasil viveu uma ditadura militar. Esses fenômenos associam-se ao aumento da pobreza e a deterioração da qualidade de vida nas periferias das metrópoles. Dentro desse contexto, Otávio, assim como outros taxistas entrevistados - entre eles, seu Fabiano, seu Luís e seu Laranjeiras -, observa:

E aí que vem o que eu quero te dizer: quando começou na década de 80 , começaram a matar taxista! Taxista começando a ser ladrão! Isso prova em jornais da época! Por que se você for folhear jornais da década de 80, você vê muito, olha: "Taxista tava com uma quadrilha e se assassinou"; "Taxista tava envolvido nisso e naquilo outro". Aí foi por isso que a idéia do papai, organizar, porque vinha um hotel cinco estrelas e pra não entrar qualquer taxista aqui, tinha que se identificar, tá? Também isso foi um fator, tá? Isso foi um fator!

Levando em conta o trecho da entrevista acima, considera-se a organização dos taxistas em Associações ou Cooperativas como uma estratégia em busca de segurança. Esta situação, no caso, diz respeito tanto ao passageiro como ao motorista. $\mathrm{O}$ relato de seu Fabiano, por exemplo, mostra uma grande apreensão quanto aos passageiros encontrados nas ruas, principalmente durante o turno da noite: "Ninguém sabe quem é quem que a gente vai apanhar na rua (...) no trânsito de Belém. Porque tem do marginal até o intelectual. Né?" Portanto, para o taxista que trabalha à noite com passageiros que apanha em frente a boates, a casas de shows, ou mesmo, andando a esmo pelas ruas, há sempre o medo e o risco da vitimização provocados por aqueles que transportam.

Em contrapartida, as narrativas podem apontar para o risco de se ter o taxista como o agente da violência, a partir dos anos 80. A existência de taxistas assaltantes é

\footnotetext{
8 "Existente desde 1976, anterior, portanto à implantação de Carajás e da estrada que liga hoje Parauapebas a Marajá [sic], passando pelo município de Curionópolis, criado a partir da atividade garimpeira. A grande explosão na área se dá a partir de 1980, ano em que a "cidade nova" de Marabá estava inundada pelas águas do [rio] Tocantins" (Vicentini, 2004, p.233).
} 
vista como conseqüência de um movimento muito mais amplo, o qual diz respeito ao próprio processo de inserção econômica da Amazônia à economia nacional. Com a descoberta do minério e a implantação dos chamados "grandes projetos de desenvolvimento" na Amazônia, Otávio afirma que, "aí você vê uma série de fatores, quais? A população nordestina veio em peso pra cá e aconteceu, o quê? Um aumento descordenado, tá, sem coordenação alguma das pessoas em Belém”.

Seu Laranjeiras corrobora essa opinião quando afirma o seguinte:

O que já veio mudar mesmo, né, pra ter problemas de assalto, outros companheiros, é que não se comportavam como um verdadeiro profissional, já veio mudar dos anos 70 pra (...) até 80,85 , mudou um pouco. Teve muita infiltração de elementos que não eram nativos, né. Vinham de outros estados e chegavam aqui, queriam trabalhar. Aí, entravam no, no, no ramo de taxista. E tinha alguns que não agia corretamente como um profissional de táxi, é, iam mais pra bandidagem! Mas os filhos daqui mesmo, sempre procuraram honrar mais esse nome, né, que era o nome que tinha, era chofer de praça, né! (...) Procuravam, é, cadastrar os motoristas de táxi pra que ela tivesse controle da, da classe, né. E já nos anos 90, por aí, assim, aí o negócio foi que ficou mais aberto e teve muito mais elementos, aumentou a classe (...) aumentou a classe e aí não houve mais o controle que tinha.

Os trabalhos de Eckert e Rocha (2005a) sobre violência urbana e "cultura do medo" indicam claramente que, para um alvo específico do medo por parte de segmentos de camadas médias em Porto Alegre, "não raro, no senso comum a tendência é conceber o 'inimigo' na figura genérica do 'pobre'” (p. 17). Os taxistas entrevistados sobre a questão da violência da cidade de Belém, em grande parte atribuíram a causa desse problema à chegada de "elementos" estranhos ao espaço urbano belemense, mais especificamente o personagem do migrante "nordestino".

Percebe-se aqui, novamente, a questão do "outro" como agente da violência, do estrangeiro - personagem simmeliano que confunde os estatutos de proximidade e distância, instaurando ambigüidades e certos conflitos (Simmel, 1983) no contexto em que se insere. Ao chegar, o estrangeiro desestrutura uma ordem supostamente bem definida e harmoniosa, pondo em cheque as possibilidades de execução dos projetos individuais dos "nativos" (Velho, 2004).

Portanto, em Belém, a "figura genérica do pobre" também é tida como uma imagem do "outro" ameaçador, pois na visão desses homens o "outro" se consubstancia 
na forma do imigrante nordestino. Apesar disso, há também a percepção entre os taxistas de que a cidade de Belém não apresentava no momento uma infra-estrutura para abrigar tal contingente populacional que chegava à urbe naquele período.

A partir de então, o mercado de motoristas autônomos começa a crescer. Com o aumento do número de taxistas, torna-se difícil o seu controle. Da mesma forma, o aumento da população acaba por minar a eficácia das medidas de segurança tomadas pelo poder público. Diante desse quadro, Otávio vê a violência urbana se generalizar. Neste sentido, as palavras de Otávio ajudam a compreender a necessidade colocada por Peirano (1983) de, no caso de uma metrópole como Belém, situá-la no processo de consolidação do Estado-Nação brasileiro. As mudanças no ofício de taxista seguem a trajetória urbana de Belém que, por sua vez, se inserem em um processo de integração da urbe e da região aos projetos econômicos de um Estado Nacional (Vicentini, 2004).

É importante ressaltar que, embora elencados aqui separadamente, os fatores que contribuíram para a criação das Associações ou Cooperativas estão interligados, pois fazem parte de um mesmo processo sócio-histórico. Esta assertiva é confirmada por um fator adicional. Em meio às ondas de imigração vividas na cidade de Belém nos anos 80 e o crescimento do comércio informal, o então governador teria "liberado" certo número de placas de táxi, o que resultou na duplicação do número de carros "na praça". A ação do governador foi um fato comentado pela maioria dos motoristas que buscaram explicar as origens da grande concorrência existente no mercado de trabalho dos taxistas nos dias de hoje. Um deles foi Neto, diretor do STEPA (Sindicato dos Taxistas do Estado do Pará).

$\mathrm{Na}$ época do governo do Jader Barbalho, naquela época, nós tínhamos numa faixa de 2500 táxis e o Jader Barbalho deu mais 2500 permissões. Então, ela, hoje o táxi, a procura... a oferta é maior do que a procura! O que diz a lei mundial? Que teria 500 pessoas pra um táxi. Então hoje ela é muito maior (...) Então, na realidade era pra ter 3500 táxis no máximo! Se a gente fosse pelo cálculo do IBGE, né, chegaria aos 3500 táxis, no máximo! (...) Ano passado nós fizemos um recadastramento e nós chegamos a essas 5.427 permissões cadastradas, que é um número exato.

Seu Fabiano, ao recordar-se das condições e perspectivas de trabalho na época em que começou a carreira de taxista, também recorre à mesma explicação para o problema da grande concorrência na praça: 
Aí, naquele tempo, taxista ganhava dinheiro, né! Nós tínhamos 3.478 táxis. Hoje nós tamo numa proporção de 5.790 táxi cadastrados. No total hoje, que abrange entre Belém e Ananindeua, numa proporção de 13.000 rodando. Então tem muito táxi (...) muito táxi em Belém!

Embora os números não coincidam - e não é de nosso interesse uma análise quantitativa exata - eles apontam para um mesmo processo, qual seja: a hipertrofia do mercado em relação ao ofício de condutor de táxi a partir dos anos 80. Observamos, assim, a criação das Associações ou Cooperativas como tentativas de administrar a concorrência intra-classe e adquirir uma clientela específica dentro de um contexto de forte concorrência. Tal questão ficou evidenciada em momentos como o que Neto, apoiado em um mapa que portava no momento da entrevista, indicou somente na Avenida Presidente Vargas a existência de 27 pontos de táxi.

Dessa forma, a organização dos taxistas em associações/cooperativas atenderia às necessidades dos motoristas e da população, posto que o passageiro pode identificar de que ponto está saindo o táxi que o transporta e, da mesma forma, o motorista conhece a procedência de seu cliente, pois este requisitou a presença do táxi através de uma ligação telefônica. Procura-se, assim, conhecer e cadastrar os clientes. Em contrapartida, os motoristas de uma Associação ou Cooperativa também são todos cadastrados e identificados, tendo esse procedimento o objetivo de controlar as ações dos associados e, bem como, de não permitir a entrada ou permanência de um sujeito que possa ser considerado nocivo.

Porém, muitos taxistas ainda estabelecem relações de nível pessoal com seus clientes, sendo requisitados diretamente através de seu telefone particular ao invés do telefone do ponto. Aqui, parece evidente que por trás da estrutura "moderna" criada para otimizar os serviços e diminuir os riscos do trabalho, consistindo de um aparato tecnológico e burocrático entre os motoristas e os seus clientes, há margens de negociações entre motoristas e clientes que escapam ao controle da organização, uma vez que envolvem interações intersubjetivas, inclusive, quanto a negociação dos preços da corrida.

Portanto, apesar do telefone do ponto ou da associação "de fato e de direito", mesmo assim, existe espaço para a tentativa de cativar o passageiro através de atributos relativos às qualidades pessoais do motorista e a negociação de valores relativos ao 
transporte do passageiro. Dentro de um sistema que busca padronizar e organizar, o taxista ainda possui liberdade para optar pela busca de um diferencial em relação a outros profissionais da mesma área.

Neste sentido, as transformações no ofício indicam formas de associação e de "agenciamentos coletivos" que "unem em pontilhado" (Maffesoli, 1987) os profissionais taxistas - existem várias cooperativas distribuídas pelos bairros de Belém -, uma vez que os reúne em grupos (enquanto classe profissional), de acordo com os seus interesses, considerando ainda os critérios éticos que regem a categoria. Entretanto, os profissionais buscam manter certa autonomia quando atuam no mundo urbano, uma vez que a existência de uma associação não diminui a margem de manobra e de liberdade de atuação dos motoristas.

Sendo assim, na interação motorista/cliente, mais especificamente no que se refere à prestação e ao uso do serviço de táxi, percebe-se, por vezes, a tentativa de ambos experimentarem, a partir de uma dimensão intersubjetiva, a possibilidade de estabelecer formas de sociação pautadas no vínculo segurança-economia. Tal questão é extremamente significativa quando pensamos as trajetórias urbanas que os motoristas percorrem ao longo de sua labuta, quando, necessariamente, realizam negociações diante do campo de possibilidades que se apresenta no panorama da vida urbana (Velho, 2004), seja nos termos das relações que estabelecem com os clientes (amizade, confiança, camaradagem, entre outras) das negociações dos preços da corrida e, mesmo, da liberdade para atuar em pontos diversos da cidade.

Seguindo esta lógica da liberdade de atuação seu Luís (48 anos) afirma que "ficar sozinho é legal!", constituindo, aos nossos olhos, uma figura peculiar de profissional, ou seja, a de um taxista independente. Segundo este senhor, as regras de conduta para os taxistas estabelecidas dentro de agrupamentos como Associações e Cooperativas seriam bastante rígidas, arbitrando, inclusive, sobre a qualidade do barbear do motorista, por exemplo. Tendo pertencido durante um período de tempo à Cooperdoca ${ }^{9}$, ele reflete acerca de algumas exigências estabelecidas pelo regulamento da referida Cooperativa:

\footnotetext{
${ }^{9}$ Cooperativa de taxistas localizada na esquina da travessa Boaventura da Silva com a Avenida Visconde de Souza Franco (Doca). Tal ponto atende basicamente três bairros de classe média/média alta, quais sejam, Nazaré, Umarizal e parte do Reduto.
} 
É, ficar sozinho é legal! (...) Ali são muitos. Aí, o cara fica assim: qualquer erro teu, 30 dias. Aí, os cara fica em cima de ti, e: "Tu errou!"

Mas que tipo de erro? (Pedro)

Tu tratou mal a cliente e ela telefonou pra lá: não, não! Vale a palavra do cliente contra a dele. Pega 30 dias! Tu podes rodar lá, mas não com a farda da Cooperdoca. Pode pegar passageiro fora, não tem problema, mas por telefone tu não pega nenhum. Deixa passar os 30 dias (...) viu? Se a pessoa for pro aeroporto e esquecer uma bolsa e você não voltar pra deixar no aeroporto, sendo que você viu, fica penalizado por 60 dias: má intenção! Se você chamar o carro, por exemplo, da Cooperdoca: "Quero o carro 4 horas da manhã, que eu vou pro aeroporto". Se o carro chegar 4:20, se você já tiver saído daqui, ele pega mais de 80 dias. Que o cliente já não vai mais te chamar, não vai chamar a Cooperdoca, com raiva, tudo porque ele não saiu no horário certo, chegou atrasado. Aí, as norma, aí da Cooperdoca são rígida. Você não pode trabalhar sem seu uniforme. O único dia que você pode trabalhar, assim, esporte como eu tô é domingo. E segunda-feira você já começa a trabalhar normalmente com a sua farda. Porque se você não for de farda pra trabalhar você não trabalha, fica suspenso, 2 dias!

Ele afirma também que o pertencimento a um grupo organizado acaba por restringir a liberdade de atuação do motorista. Teriam sido dessa ordem as razões que motivaram seu Luís a deixar de participar de uma cooperativa? Nota-se, seu Luís ainda tentou de alguma maneira atender a uma clientela específica, no caso, os moradores de um edifício de classe média localizado no bairro do Reduto. Seu Luís passou, então, a estacionar seu táxi em frente ao edifício e esperar os moradores que precisassem de seus serviços. Com o tempo, começou a ser considerado pelos moradores como uma "pessoa de confiança" e conseguiu construir uma clientela fixa. Na história de seu Luís, podem ser apreendidas as mesmas necessidades apontadas por Neto e Otávio na criação de pontos organizados, ou seja, estabelecer-se em um lugar fixo e possuir uma rede de clientes regular e conhecida, configurando uma relação de confiança para ambos os personagens, o taxista e o passageiro.

\section{As modificações do ofício de taxista ao longo do tempo}

Entre as transformações vividas pelos profissionais taxistas em seu ofício registra-se o que diz respeito à forma de pagamento realizada pelos clientes. Os taxistas mais antigos relatam que não existia o aparelho denominado taxímetro, instrumento 
responsável por calcular a relação espaço percorrido/quantia a pagar. O preço era então combinado previamente, antes da corrida. Seu Mário, um antigo taxista que trabalha na Avenida Presidente Vargas, conta que:

Com certeza, o tempo dos carros de praça, que num tinha a, a, o, que não tinha o marcador como tem agora que é o taxímetro, né. Nesse tempo era no contrato, você contratava, chamava-se os carro de aluguel, né. Você contratava o, o motorista pra ir a um casamento, pra fazer um batizado, pra ir buscar a, o pessoal no cinema, pra levar... Você dava aquele valor como... você calculava, o que desse você dava, cinco cruzeiro, três cruzeiro, né. E assim a gente foi trabalhando. Foi quando que surgiu a idéia de táxi com relógio, com taxímetro, né, pra valorizar a corrida.

Nos dias de hoje, além da existência do taxímetro, observa-se em alguns pontos a presença do aparato tecnológico que possibilita aos clientes pagarem as corridas através do cartão de crédito, o que facilita o trânsito dos sujeitos e confere certo distanciamento à relação com o motorista. Não mais se trata da mera impessoalidade moderna da circulação do dinheiro (Simmel, 1998) - uma vez que as formas de pagamento não eram, necessariamente, realizadas dessa forma no passado -, mas a do cartão de crédito de sujeitos pós-modernos que experimentam a virtualidade do "nãolugar" (Augé, 1994) evidenciada pelo fluxo de signos monetários que o cartão possibilita, paradoxalmente, ao viverem o lugar que é a urbe sobre o carro conduzido pelo taxista. Contudo, em muitas ocasiões de nosso próprio cotidiano os motoristas ainda deixam os taxímetros de lado e combinam anteriormente à corrida um preço com seus clientes, escapando de ambas as formas de impessoalidade apontadas acima.

As modificações no ofício de taxista foram segundo Otávio, essenciais para a sobrevivência profissional da classe ao longo do tempo, assim como para a manutenção da qualidade dos serviços prestados à população. Isso nos leva a refletir acerca do fato de que não são apenas profissionais de ofícios, denominados, por vezes, de "tradicionais", que vivem a tensão entre a utilização de formas mais "remotas" em oposição àquelas mais "modernas”, durante o desempenho de suas atividades laborais ${ }^{10}$.

Diante do incremento populacional, do aumento da violência urbana e da hipertrofia do mercado de trabalho - o que ocasiona uma grande concorrência entre os profissionais -, os taxistas são também impelidos a buscar novas táticas e estratégias, de

${ }^{10}$ Como foi demonstrado em nossas pesquisas relativas ao ofício do barbeiro no distrito de Icoaraci, realizada durante o ano de 2006. 
forma a atualizar suas "artes de fazer" (Certeau, 1994). Os taxistas, da mesma forma que muitos outros profissionais, devem fazer uso dos jogos e das combinações entre o "tradicional" e o "moderno", re-significando o primeiro, a fim de continuarem trabalhando com sucesso.

Quando nos referimos às modificações das atividades dos motoristas autônomos em Belém, levamos em conta as tendências relativas à ocupação de outros nichos de labuta na cidade, observadas durante o trabalho de campo, bem como os relatos dos taxistas com os quais conversamos. Não apontamos aqui, para um processo homogêneo simplesmente, pois, além de possuírem uma margem de liberdade para aderir ou não às "novas práticas" que envolvem seu métier, é preciso lembrar que entre as características dos centros urbanos contemporâneos, como propõem Eckert e Rocha (2005), aparece, não apenas, a diversidade sócio-cultural, mas também a multiplicidade de tempos vividos por seus habitantes. Portanto, ao tratarmos sobre o tema das modificações dentro da profissão de taxista, devemos levar em conta a forma como estes profissionais se relacionam com seu local de trabalho e como este se inscreve na paisagem urbana enquanto um lugar detentor de memórias ${ }^{11}$.

Outra mudança reconhecida hoje em dia pelos taxistas é a da qualidade estética dos automóveis e o aperfeiçoamento dos serviços prestados. Clientes mais exigentes, como pontuou seu Luís; o incentivo por parte dos sindicatos e das associações/cooperativas e a concorrência - tanto intra-associativa quanto em relação aos demais taxistas -, cooperam para que os taxistas sejam compelidos a buscar uma diferenciação pessoal, o que reflete positivamente na melhoria da qualidade de seu trabalho e na prestação de serviço aos usuários de táxi.

Esse diferencial pode se manifestar na qualidade de serviços e do automóvel (geralmente, muito limpos e novos), bem como na especialização em assuntos aparentemente alheios à condução de passageiros. Um exemplo disso é seu Itamar (53 anos), um antigo taxista que iniciou a sua carreira nos anos 70 e um dos primeiros taxistas a serem entrevistados durante o processo de pesquisa. Este senhor declarou que costuma efetuar o pagamento de contas e realizar a declaração de imposto de renda de alguns de seus clientes, oferecendo assim, um plus aos clientes e reafirmando laços de confiança com os mesmos. Por outro lado, ao comentar com outras pessoas o fato de

\footnotetext{
${ }^{11}$ Utilizando o trabalho de Pierre Nora (1989), evocamos os lugares de memória, enquanto locais de intensa convergência de lembranças e imagens e que possuem um papel fundamental na construção identitária de um grupo. Ao lugar de memória de Nora, opõem-se o não-lugar de Augé (1994), relacionado à idéia de fluxo, deslocamento próprios da hiper-modernidade. Portanto, o primeiro indica o enraizamento ao lugar enquanto o segundo aponta para o contrário.
} 
estarmos realizando uma pesquisa sobre taxistas, fomos advertidos da existência de motoristas próximos a um de nossos loci de pesquisa os quais seriam, supostamente, conhecedores e fomentadores de esquemas de prostituição e venda de drogas para turistas.

Cabe aqui apenas apontar que os expedientes de ambos os motoristas aparecem como formas de especialização em atividades em princípio fora da alçada de taxistas, mas que passam a ser complementares no sentido de que constituem estratégias de permanência no negócio de táxi e movimentação pelos meandros de um mercado de trabalho hipertrofiado, que os coloca como agentes sociais em pleno processo de interação com o mundo urbano, para além de sua especialidade laboral.

\section{Autonomia e concorrência}

Os taxistas que entrevistamos consideram-se trabalhadores autônomos. "Eu sou um trabalhador autônomo!", respondeu seu Itamar quando questionado sobre esse tema. A veemência de sua afirmação vem do fato de que na maioria das vezes o taxista é dono de seu meio de produção, ou seja, do táxi. Além do mais, embora esteja associado a um grupo de trabalhadores, não há freqüência a ser cumprida e nem um expediente a ser vencido. $\mathrm{O}$ taxista trabalha conforme a sua vontade ou necessidade, portanto, detém certa autonomia diante de outros profissionais que atuam no mundo urbano. No entanto, o que se percebe nos dias de hoje é o aumento da necessidade de trabalhar, uma vez que a jornada de trabalho desses profissionais tem aumentado com o passar do tempo ${ }^{12}$.

Otávio, ao refletir sobre as conquistas e percalços da atual geração de taxistas, tendo como base as condições de trabalho anteriores à criação da Associação dos Taxistas da Praça da República, nos dá uma idéia do processo que culminou nas atuais condições de trabalho enfrentadas pela "classe taxista":

Agora se ela, al... alcançou alguma liberdade econômica em relação às anteriores, claro, ela galgou sim. Hoje em dia você vê pela qualidade dos táxis. Na década de 70 , na década de 80 , você via carros sucateados, né! Hoje em dia você vê carros melhores. Mas por quê? Isso foi uma série de fatores, tais quais:

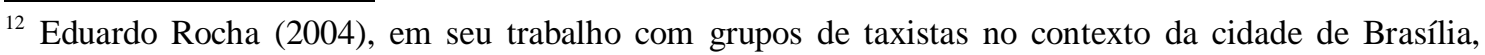
aponta para uma prática comum aos motoristas que trabalham em carros alugados junto a outros taxistas. Esses motoristas, diante da necessidade de pagar o aluguel ao proprietário do carro que dirigem e ainda garantirem o seu sustento, acabam "dormindo na pedra", ou seja, passando a noite no ponto de táxi. Dependendo do taxista e de sua necessidade, essa noite pode converter-se em duas, três, chegando, mesmo, a uma semana de trabalho no ponto sem retorno ao domicílio. Sobre este assunto, ainda há um vídeo etnográfico disponível em: http://br.youtube.com/watch?v=XJbrqhUf1NU
} 
é... políticas públicas em relação à isenção dada pelo governo federal e estadual, tá! Você, você vê a oferta, a demanda maior de carros, tá, aonde antigamente na década de 70 a classe média pegava táxi porque ela não tinha condições de comprar. Hoje, a classe média compra carro aí como se compra roupa! Então, hoje já houve uma redução disso só que por outro lado, a população cresceu, então, aumentou proporcionalmente as corridas em relação ao número de crescimento populacional. (...) Hoje os pontos, eles são... hoje os pontos, eles sofreram uma mudança. Lógico, era público e notório que deveria se mudar. Por quê? Tinha épocas, no começo de 70, 75, na década de 70, as pessoas faziam fila pra pegar táxi. No Ver-o-Peso ${ }^{13}$ era assim. No Ver-o-Peso as pessoas faziam fila esperando carro, táxi. Táxi, o taxista, a hora que ele quisesse sair da sua casa ele saía, ele sabia que ele dia faturar dinheiro. Hoje, se ele não sair cedo e voltar tarde, ele não ganha dinheiro. Mas naquela época, não...

A parte final do trecho acima é bastante sugestiva do ponto de vista de explicitar a maneira pela qual os taxistas representam as modificações de seu ofício em estreita relação com as transformações sofridas pelo espaço urbano de Belém. A imagem da fila de pessoas à espera de um táxi é importante, especialmente por sua forte carga antitética em relação às atuais condições de trabalho observadas e relatadas pelos motoristas. Hoje, diferentemente, o que se observa é a fila de táxis à espera de um passageiro.

\footnotetext{
${ }^{13}$ Escreve o literato paraense Dalcídio Jurandir em 1960, sobre o Ver-o-Peso, o seguinte: "Região de Belém ao lado da qual, no final do século XIX, foi construído, pelos ingleses, um porto para exportação do látex. Em 1/12/1901, o Ver-o-Peso ganhou o Mercado de Ferro. Hoje, a região corresponde a um ancoradouro (onde aportam barcos de pesca, canoas, que trazem diversos produtos das Ilhas para serem vendidos ali), a uma Feira e ao Mercado de Ferro. Nessa região se comercializam plantas medicinais e "mágicas", banhos-de-cheiro, verduras, carnes, peixes, frutos da terra e importados, comida pronta, artesanato. O nome da região tem a sua origem no período colonial, quando na área funcionava a Casa do Haver-do-Peso, onde era pesada a mercadoria vinda do interior, para a cobrança de impostos devidos à Coroa Portuguesa". (Jurandir, 2004:548)
} 


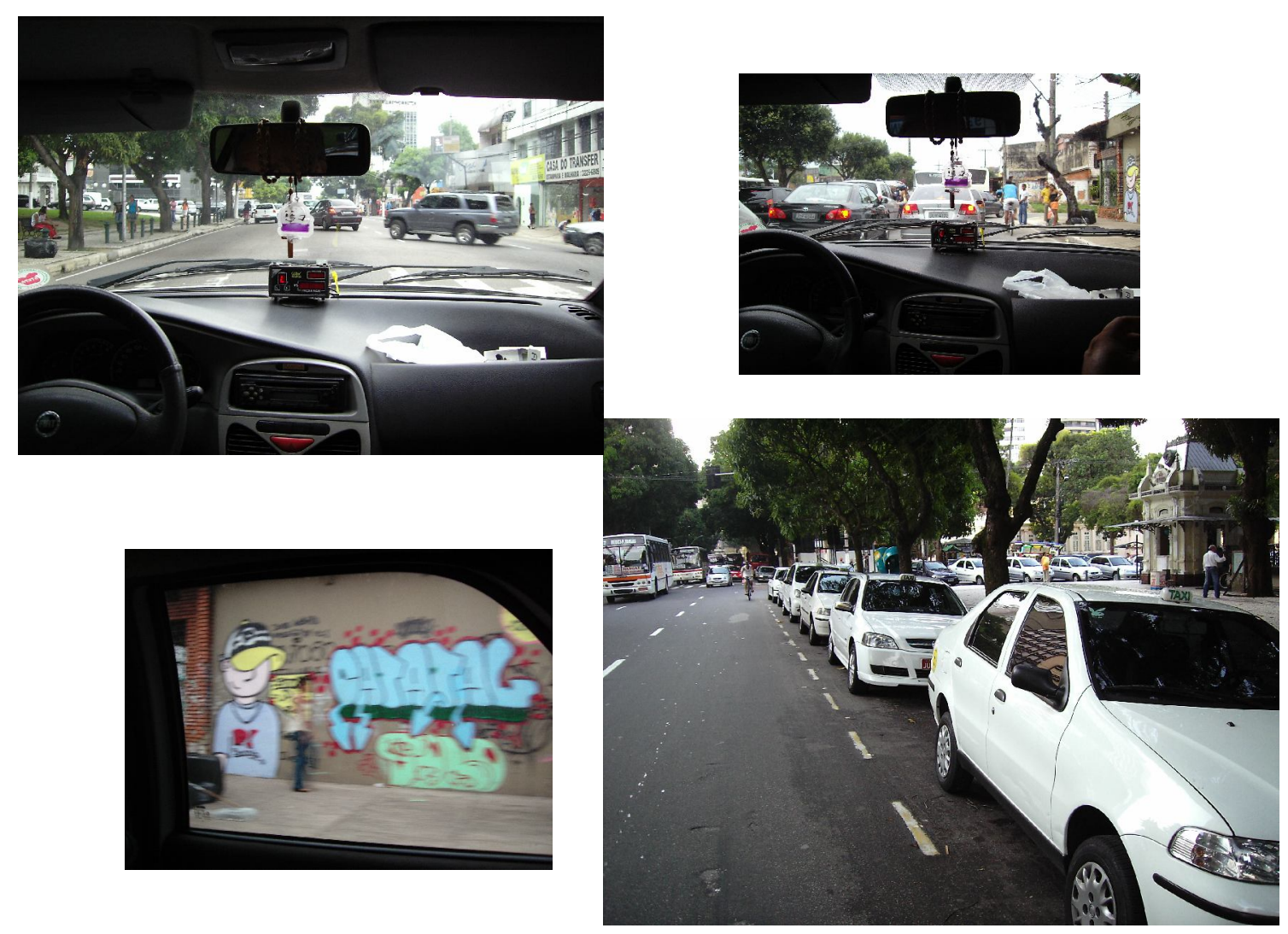

No entanto, tal imagem também aponta para a mudança nos estilos de vida de certa camada da população de Belém, pois atualmente "a classe média compra carro aí como se compra roupa" (Otávio), ou ainda, "hoje é muito fácil comprar um carro" (Seu Itamar). Tais afirmações são oriundas da experiência cotidiana desses motoristas que percorrem as ruas da cidade e observam um número de veículos cada vez maior. Segundo estes senhores, o mercado dos taxistas também se encontra sobrecarregado.

Por outro lado, Neto também coloca o problema do aumento da jornada de trabalho exercida pelos trabalhadores, associando-o à "doença do estresse", vista como consequiência do período prolongado que os motoristas devem permanecer no trânsito de Belém:

A consequiência do taxista é que ele fica no estresse, ele termina adoecendo do estresse... Porque antigamente tu rodava oito horas, fazia o teu dinheiro e tu ia embora. Hoje o taxista aumentou o número de carga horária pra quase quatorze, quinze horas de trabalho por dia... pra poder manter uma qualidade pra sua família, né, um padrão de vida pra sua família. 
Desse modo, embora sejam trabalhadores autônomos e não recebam salários ou possuam patrões, os taxistas estão sujeitos a uma "subordinação formal ao capital" 14 uma vez que seus ganhos e a sua jornada de trabalho são condicionados pelo mercado. Não se pode esquecer também a violência urbana, vista como um fator externo limitador da liberdade individual e da autonomia do taxista. Mesmo assim, eles procuram trabalhar o máximo que suas forças permitirem, como atesta o depoimento de Neto. Uma medida comumente utilizada é também o aluguel do carro para taxistas que ainda não possuem um automóvel próprio. Essa medida pode possuir alguns riscos, visto que ela consiste na entrega do carro nas mãos de uma terceira pessoa. No entanto, ela pode ajudar o motorista a manter a produtividade de seu trabalho em momentos em que seu carro estaria ocioso.

\section{Considerações Finais}

Ao serem instigados pelos pesquisadores, estes senhores falaram sobre sua trajetória de vida e sobre as mudanças sofridas na paisagem da cidade de Belém. Durante tais relatos, as modificações, dilemas, possibilidades e limites do ofício de taxista, vieram à tona como elementos indissociáveis do processo de expansão urbana e mudança no espaço vivenciado por eles na cidade de Belém. Assim, os impactos do processo de inserção da Amazônia paraense no sistema econômico mundial se manifestam na urbe e são notados no plano micro por sujeitos - no nosso caso os taxistas - que estão em constante interação com o mundo urbano.

A migração desordenada, o surgimento do taxímetro, a popularização do automóvel, o aumento da violência urbana e a figura do chofer são alguns dos temas tratados neste artigo que se ligam estreitamente à trajetória individual de certos taxistas, mas também com a consolidação dos taxistas enquanto uma classe "pulverizada" em diversos bairros belemenses na forma de cooperativas e associações à procura de uma clientela regular.

Para o caso deste estudo, a memória coletiva dos taxistas ajuda a situar as experiências sociais específicas, vividas na cidade de Belém, a partir da perspectiva das sociedades complexas urbano-industriais. Tal questão está relacionada, por certo, a contextos maiores como é o caso da nação, por exemplo, intimamente ligada ao processo de globalização cultural e econômica.

\footnotetext{
${ }^{14}$ Esta é a condição de diversas categorias profissionais que também trabalham "por conta própria", a exemplo dos pescadores vigienses pesquisados por Violeta Loureiro (1985).
} 
É necessário considerar, entretanto, que as lembranças contidas nos relatos de taxistas não trazem uma pretensa experiência exata e concreta dos sujeitos dentro de um processo histórico entendido como real, mas as interpretações dos narradores acerca da sua realidade apreendida no cotidiano. Possuindo como matéria prima os acontecimentos de um determinado período e a vivência dos sujeitos dentro de grupos específicos, a memória permite o estudo das aspirações, sentimentos e representações provocadas pelo mundo urbano captado através de uma perspectiva temporal pelo taxista e pelo etnógrafo.

\section{Referências Bibliográficas}

BENJAMIN, Walter. “O Narrador. Considerações sobre a obra de Nikolai Leskov”. In: BENJAMIN, W. Magia e Técnica, Arte e Política. Ensaios sobre Literatura e História da Cultura. São Paulo: Brasiliense, 1996.

AUGÉ, Marc, Não-Lugares - Introdução a uma Antropologia da Supermodernidade; tradução, Maria Lúcia Pereira. Papirus. Campinas, SP. 1994.

CERTEAU, Michel de. A Invenção do Cotidiano. Artes de fazer. vol. I. Petrópolis: Vozes, 1994.

CLIFFORD, James. "Culturas Viajantes". In: O Espaço da Diferença. Antonio A. Arantes (org). Campinas, SP: Papirus, 2000.

DAMATTA, Roberto. A casa e a rua. Rio de Janeiro: Rocco, 1997.

ECKERT, Cornelia; A cultura do medo e as tensões do viver a cidade: narrativa e trajetória de velhos moradores de Porto Alegre. Porto Alegre: Banco de Imagens e Efeitos Visuais, PPGAS/UFRGS, 2000. 36 f. - (Iluminuras; n. 18)

ECKERT, Cornelia; ROCHA, Ana L. C. da. O porto pouco seguro: estudo da cultura do medo em Porto Alegre. Porto Alegre: Banco de Imagens e Efeitos Visuais, PPGAS/UFGRS, 2005 a. $32 \mathrm{f}$ - (Iluminuras n. 80)

ECKERT, Cornelia; ROCHA, Ana L. C. da. O Tempo e a Cidade. Porto Alegre: Editora da UFRGS, 2005 b.

ELIADE, Mircea. O Mito do Eterno Retorno. São Paulo: Mercuryo, 1992.

GELL, Alfred. "How to read a map: remarks on the practical logic of navigation". Man, New Series, Vol. 20, No. 2. (Jun., 1985), pp. 271-286.

JURANDIR, Dalcídio. Belém do Grão-Pará. Belém: Edufpa; Rio de Janeiro: Casa Rui Barbosa, 2004.

LOUREIRO, Violeta Refkalefsky . Os parceiros do mar: natureza e conflito social na pesca da Amazônia. Belém: MPEG/CNPq, 1985.

MAFFESOLI, Michel. O tempo das tribos. O declínio do individualismo nas sociedades de massa. Rio de Janeiro: Forense-Universitária, 1987.

MAFFESOLI, Michel. Sobre o nomadismo. Vagabundagens pós-modernas. Rio de Janeiro: Record, 2001.

NORA, Pierre. Between Memory and History: les lieux de mémoire. Representations, No. 26, Special Issue: Memory and Counter-Memory. (Spring, 1989), pp. 7-24.

OLIVEN, R. G. A Parte e o Todo. A diversidade cultural no Brasil-Nação. Petrópolis, Vozes, 1992.

OLIVEN, R. G. Desterritorialização. Porto Alegre, Porto e Vírgula, n.27, 1996, pp.14-16. 
HALBWACHS, Maurice. A memória coletiva. São Paulo: Centauro, 2006.

PEIRANO, Mariza. "Etnocentrismo às Avessas: O Conceito de 'Sociedade Complexa'". In: Revista de Ciências Sociais. Rio de Janeiro, 1983.

PERLONGHER, N. Territórios Marginais. Papéis avulsos. UNIUCAMP, n9, CIEC, São Paulo, 1989.

ROCHA, Ana. L. C. da.; ECKERT, Cornelia. Os jogos da memória. ILHA, Florianópolis: 2000, ps. 71-84.

ROCHA, Eduardo C. Estranhos Encontros: aproximação etnográfica do táxi, sistema de transporte individual de passageiros. 2004. 80 F. Monografia (Bacharelado em Antropologia). Brasília: Universidade Nacional de Brasília - Departamento de Antropologia.

SIMMEL, Georg. O dinheiro na cultura moderna. SOUZA, Jessé e ÖELZE, Berthold (orgs.). Simmel e a modernidade. Brasília: Unb, 1998, p.23-40.

SIMMEL, Georg. Sociologia. Org. Evaristo de Moraes Filho, São Paulo: Ed. Ática, 1983.

VELHO, Gilberto. Individualismo, anonimato e violência na metrópole. Horizontes Antropológicos, Porto Alegre, ano 6, n.13, p.15-29, junho de 2000.

VELHO, Gilberto. Individualismo e Cultura. Rio de Janeiro: Jorge Zahar, 2004.

VELHO, Gilberto. Projeto e Metamorfose: antropologia das sociedades complexas. Rio de Janeiro: Jorge Zahar Ed., 2003.

VICENTINI, Yara. Cidade e História na Amazônia. Curitiba: Editora UFPR, 2004.

ZUKIN, Sharon. "Paisagens urbanas pós-modernas: mapeando cultura e poder", in: $O$ espaço da diferença. Antônio A. Arantes (org.). Campinas, SP: Papirus, 2000. 